\title{
The Effects of Different Concentrations of Bay Leaf Extract on Shelf Life of Preserved Scad Fish
}

\author{
Pramaziyah Fuaidah, Juni Triastuti", and Heru Pramono \\ Department of Marine, Faculty of Fisheries and Marine, Universitas Airlangga, Surabaya-60115, Indonesia \\ *Corresponding author's Email: juni.triastuti@fpk.unair.ac.id ; (DORCiD: 0000-0003-4378-1946
}

\begin{abstract}
Scad fish (Decapterus kurroides) is the most productive fish species. To provide the added value, fishermen can process scad fish into various forms of processed products, such as preserved fish, which extend the shelf life. In order to extend the shelf life of canned fish, natural preservatives could be used that contain antimicrobial agents, such as bay leaves. The present study aimed to determine the effects of bay leaf extract in different concentrations on the shelf life of preserved scad fish. In the present study, the completely randomized design was used as an experimental research method. The treatments given differed in terms of the concentration of the bay leaf extract. The groups were treated as the scad fish without bay leaf extract (A), scad fish soaked in $6 \%$ of bay leaf extract (B), scad fish soaked in $7 \%$ of bay leaf extract (C), scad fish soaked in $8 \%$ of bay leaf extract (D), and scad fish soaked in $9 \%$ of bay leaf extract (E). The analyzed parameters included the total plate count, $\mathrm{pH}$, and water level test using Analysis of Variance (ANOVA). The supportive parameters observed included an organoleptic test. The results indicated that the lowest total bacterial count from the beginning to the end of the experiment (18 hours) occurred on treatment C ( $7 \%$ of bay leaf extract addition), which was $1.54 \times 103$ to $5.85 \times 106$. Regarding the water level test from the beginning to the end of the experiment, treatment A (control) was not significantly different from other treatments. The difference in the concentration of bay leaf extract on scad fish effectively inhibited the growth of bacterial colonies. In conclusion, adding bay leaf extract to scad fish could inhibit bacteria for up to 12 hours. Treatment $\mathrm{C}$ ( $7 \%$ of bay leaf extract) gave the best results since this concentration level could inhibit the bacteria on scad fish.
\end{abstract}

Keywords: Bay leaf, Preservation, Scad fish, Shelf life

\section{INTRODUCTION}

Scad fish (Decapterus kurroides) is the most productive fish species, accounting for $52 \%$ of the total catch of approximately 2323365 tons per year. In addition, scad fish comes at a relatively low price. To achieve added value, fishermen process scad fish into various forms of processed products, such as petis (fish paste) and preserved fish. Preserved fish is one of the most famous marine products in Indonesia due to a combination of boiling and salting. The resulting product is a preserved fish with low salt content. The traditional preservation process of boiling the fish in the salt solution is called pindang cue (Triarso, 2012; Junianingsih, 2015).

Pindang cue uses scad fish, which can be found in traditional markets and are commonly placed in paso or naya (small woven tray) without any packaging. Thus, microbial contamination occurs during the sales process. The shelf life of scad fish is approximately 1-2 days, and safety is not guaranteed. Scad fish contain high water (60\%) and protein $(27 \%)$, which are suitable for the microorganisms' growth. The maximum limit for the microorganism in food products is $5.0 \times 105$ cells/gram (Ariyani, and Yennie 2008)

Preservation is an appropriate way to extend the shelf life of scad fish. Fish preservation is a process that is aimed at developing high-quality processed fish products (in terms of color, odor, texture), offering a wide range of food and varietal products on the market, increasing the economic value of the product, as well as enhancing the shelf life of fish. Since these preserved scad fish had a limited shelf life and are prone to deterioration, fish should be stored longer to provide benefits to traders while increasing consumers' appeal. Conservation also is used to inhibit the activities of enzymes and microorganisms (Herawati, 2008).

Preservation with hazardous chemicals, such as formalin, is mostly used because the price is lower than safe preservation. The use of formalin has been constantly increasing. Thus, natural preservations are required to inhibit the growth of spoilage bacteria (Hastuti, 2010; Nafisyah, 2015). Herbs and spices native to Indonesia contain active antimicrobial substances that potentially can be used as natural preservatives. Bay leaf is one of the natural ingredients 
that can be used as a preservative, and also has many benefits to be utilized in cooking as a seasoning because of its distinctive aroma and odor, as well as its low price and easy procurement (Purwani and Muwakhidah, 2008).

Bay leaf is an ingredient that can be used as a fish preservative since it contains flavonoid, terpenoid, and tannin, which have antibacterial properties. Flavonoids inhibit bacterial growth by forming complex compounds with extracellular proteins through hydrogen bonds, that damage the cell membrane. Tannin inhibits bacterial growth by denaturating bacterial cell proteins in the cell membrane. The terpenoid inhibition mechanism for bacterial growth is to react with porin (transmembrane protein) on the external membrane of the bacterial cell wall. Bay leaf indicated good antibacterial activity against Staphylococcus aureus (Roslizawaty, 2013; Nurwijayanti, 2016). Based on the fact that bay leaf indicated sufficient antibacterial activity against Staphylococcus aureus, the present study was conducted to investigate the effects of bay leaf extract with different concentrations on the shelf life of scad fish.

\section{MATERIALS AND METHODS}

The current research used an experimental research method and the experiment design of a completely randomized design. The following is the bay leaf treatments on scad fish, scad fish without bay leaf extract treatment (A), scad fish soaked in $6 \%$ of bay leaf extract (B), scad fish soaked in $7 \%$ of bay leaf extract (C), scad fish soaked in $8 \%$ of bay leaf extract (D), and scad fish soaked in $9 \%$ of bay leaf extract (E).

The variables included in the present study were independent, dependent, and control variables. The independent variable was the bay leaf extract. The dependent variables of the study were the Total Plate Count (TPC), organoleptic value, $\mathrm{pH}$, and water level of scad fish. The control variables of the research were bay leaves, preserved scad fish, and bay leaves boiled at $90^{\circ} \mathrm{C}$ for 30 minutes.

The research procedure was divided into two stages of preparation and implementation. The preparatory stage consisted of fish processing, sterilization of tools and materials, bay leaf extraction, and preparation of Plate Count Agar (PCA) media. The implementation stage included the treatment of scad fish, marked with the letter A, B, C, D, and E. Then, the treatment was performed by mixing bay leaf extracts with the preserved scad fish. In treatment A, the scad fish were not soaked in the bay leaf extract. In treatments B, C, D, and E, the scad fish were soaked in bay leaf extract with concentrations of $6 \%, 7 \%, 8 \%$, and $9 \%$, respectively, for 30 minutes. Furthermore, the soaked scad fish were then placed into the oven for 30 minutes at a temperature of $50^{\circ} \mathrm{C}$. Then, the fish were transferred to clean containers and stored at room temperature. Afterward, the total number of bacteria, the $\mathrm{pH}$ value, water content, and the organoleptic value were observed before storage and after $3,6,9,12,15$, and 18 hours of storage.

The research parameters were the main parameters and supporting parameters. The main observed parameters entailed the TPC test, $\mathrm{pH}$, and water level. The supporting parameters observed included the organoleptic tests. The research result data were analyzed in the terms of TPC, $\mathrm{pH}$, and water level using Analysis of Variance (ANOVA) to determine the difference in the different concentrations of bay leaf extracts on the shelf life of scad fish. Duncan's Multiple Range Test was then performed to determine the differences between treatments. The data analysis for organoleptic tests used descriptive methods. The distinction between the two approaches to sensory evaluation of fish products was made to first emphasize that both of these approaches were necessary for the evaluation of this commodity. Secondly, these two aspects of sensory evaluation of fish products were not mutually exclusive but rather acted as a mutual information resource. Sensory assessment of fish products would continue to be essential in quality testing, even as with time, useful chemical tests are developed which are as efficient and cost-effective as sensory testing. In product grading, standard chemical and physical tests can only measure what is already known. The sensory assessor can measure both the known attributes of the product and assess the presence of new attributes, especially in the area of measurement of 'taint' in fish products. The factor of sensory testing is part of the definition of taint in a product ['fish that is rancid or has an abnormal odor or flavor (DFO, 1978). However, chemical testing can accurately assess the level of a particular compound in a sample, it cannot by itself, indicate what this number means relative to the final quality of the product and the action that needs to be taken as to whether the product will continue to be used as a food, or whether it has deteriorated to a point where it is no longer usable. The definition of the 'cut-off' point for taint will always be based on a human definition of this level for the particular culture in which the product is being used (York and Sereda, 2014).

\section{RESULTS}

\section{Total bacterial count}

The highest mean total bacterial count from the beginning of the experiment until the end of the experiment (18 hours) occurred in treatment A (control), which was $1.57 \times 103$ to $8.55 \times 106$. Meanwhile, the mean value of the lowest total bacterial count occurred from the beginning to the end in treatment $\mathrm{C}$ ( $7 \%$ of bay leaf extract), which was $1.54 \times 103$ to $5.85 \times 106$ (Table 1$)$. 


\section{Water level test}

The water level test utilized a moisture analyzer. The average value of the water content found in the redtail scad at the beginning of the experiment and the end of the experiment of each treatment decreased during storage at room temperature until the end of the study. The results of the ANOVA test showed that the mean value of the water level at the beginning and in hour 18 of the experiment in treatment A (control) did not significantly differ $(p>0.05)$ from the other treatments (Table 2).

\section{PH level test}

The results of the ANOVA test showed that the mean value of the water level at hour 12 in group D and hour 15 in group $\mathrm{C}$, and $\mathrm{E}$ was significantly different $(\mathrm{p}<0.05)$ from the other treatments (Table 3 ).

Table 1. Total bacterial count (CFU/gram) of Staphylococcus aureus and bacterias in Scad fish meat

\begin{tabular}{lccccc}
\hline $\begin{array}{l}\text { Observation } \\
\text { Time (hour) }\end{array}$ & $\mathbf{5}(\mathbf{0 \%})$ & $\mathbf{B}(\mathbf{6 \%})$ & $\mathbf{C}(\mathbf{7 \%})$ & $\mathbf{D}(\mathbf{8 \%})$ & $\mathbf{E}(\mathbf{9 \%})$ \\
\cline { 2 - 6 } & $1.57 \times 10^{3 \mathrm{a}} \pm 0.11$ & $1.52 \times 10^{3 \mathrm{a}} \pm 0.15$ & $1.54 \times 10^{3 \mathrm{a}} \pm 0.17$ & $1.82 \times 10^{3 \mathrm{a}} \pm 0.12$ & $1.43 \times 10^{3 \mathrm{a}} \pm 0.14$ \\
1 & $8.25 \times 10^{3 \mathrm{a}} \pm 0.04$ & $6.85 \times 10^{3 \mathrm{ab}} \pm 0.05$ & $5.1 \times 10^{3 \mathrm{c}} \pm 0.07$ & $5.95 \times 10^{3 \mathrm{bc}} \pm 0.04$ & $6.45 \times 10^{3 \mathrm{~b}} \pm 0.07$ \\
6 & $2.58 \times 10^{4 \mathrm{a}} \pm 0.04$ & $2.22 \times 10^{4 \mathrm{ab}} \pm 0.13$ & $1.72 \times 10^{4 \mathrm{~b}} \pm 0.07$ & $2.22 \times 10^{4 \mathrm{ab}} \pm 0.12$ & $2.11 \times 10^{4 \mathrm{ab}} \pm 0.11$ \\
9 & $6.60 \times 10^{4 \mathrm{a}} \pm 0.04$ & $6.65 \times 10^{4 \mathrm{a}} \pm 0.03$ & $5.11 \times 10^{4 \mathrm{~b}} \pm 0.03$ & $6.50 \times 10^{4 \mathrm{a}} \pm 0.05$ & $5.94 \times 10^{4 \mathrm{a}} \pm 0.02$ \\
12 & $2.78 \times 10^{5 \mathrm{a}} \pm 0.02$ & $2.23 \times 10^{5 \mathrm{~b}} \pm 0.10$ & $1.47 \times 10^{5 \mathrm{c}} \pm 0.02$ & $1.87 \times 10^{5 \mathrm{~b}} \pm 0.03$ & $2.18 \times 10^{5 \mathrm{~b}} \pm 0.08$ \\
15 & $2.35 \times 10^{6 \mathrm{a}} \pm 0.08$ & $2.12 \times 10^{6 \mathrm{a}} \pm 0.07$ & $1.45 \times 10^{6 \mathrm{~b}} \pm 0.05$ & $1.94 \times 10^{6 \mathrm{a}} \pm 0.06$ & $2.08 \times 10^{6 \mathrm{a}} \pm 0.08$ \\
18 & $8.55 \times 10^{6 \mathrm{a}} \pm 0.04$ & $7.17 \times 10^{6 \mathrm{ab}} \pm 0.04$ & $5.85 \times 10^{6 \mathrm{~b}} \pm 0.06$ & $6.1 \times 10^{6 \mathrm{~b}} \pm 0.08$ & $6.57 \times 10^{6 \mathrm{~b}} \pm 0.07$ \\
\hline
\end{tabular}

The different superscript letters in the same column shows a significant difference $(\mathrm{p}<0.05)$. CFU: Colony-forming unit, SD: Standard deviation.

Table 2. Water level test of scad fish meat

\begin{tabular}{lcc}
\hline Treatment $(\%)$ & The water level at the beginning of the study (\%) & The water level at the end of the study (\%) \\
\hline A $(0 \%)$ & $45.97^{\mathrm{a}} \pm 1.34$ & $34.74^{\mathrm{a}} \pm 6.87$ \\
B $(6 \%)$ & $48.6^{\mathrm{a}} \pm 4.49$ & $34.133^{\mathrm{a}} \pm 8.88$ \\
C $(7 \%)$ & $47.41^{\mathrm{a}} \pm 2.44$ & $33.78^{\mathrm{a}} \pm 11.02$ \\
D $(8 \%)$ & $43.08^{\mathrm{a}} \pm 5.89$ & $37.81^{\mathrm{a}} \pm 9.25$ \\
E $(9 \%)$ & $45.94^{\mathrm{a}} \pm 5.42$ & $36.51^{\mathrm{a}} \pm 7.62$ \\
\hline
\end{tabular}

Remarks: The notation indicated by different superscript letters in the same column shows a significant difference $(\mathrm{p}<0.05)$.

Table 3. PH Level of scad fish meat

\begin{tabular}{lccccc}
\hline Observation time & $\mathbf{A}(\mathbf{0 \%})$ & $\mathbf{B}(\mathbf{6 \%})$ & $\mathbf{C}(\mathbf{7 \%})$ & $\mathbf{D}(\mathbf{8 \%})$ & $\mathbf{E}(\mathbf{9 \%})$ \\
\hline 1 & & & & & \\
3 & $7.05^{\mathrm{a}} \pm 0.40$ & $6.99^{\mathrm{a}} \pm 0.42$ & $6.78^{\mathrm{a}} \pm 0.24$ & $6.78^{\mathrm{a}} \pm 0.21$ & $6.73^{\mathrm{a}} \pm 0.09$ \\
6 & $6.89^{\mathrm{a}} \pm 0.57$ & $6.88^{\mathrm{a}} \pm 0.40$ & $6.73^{\mathrm{a}} \pm 0.12$ & $6.7^{\mathrm{a}} \pm 0.23$ & $6.6^{\mathrm{a}} \pm 0.11$ \\
9 & $6.92^{\mathrm{a}} \pm 0.48$ & $6.95^{\mathrm{a}} \pm 0.34$ & $6.75^{\mathrm{a}} \pm 0.10$ & $6.7^{\mathrm{a}} \pm 0.21$ & $6.7^{\mathrm{a}} \pm 0.08$ \\
12 & $6.85^{\mathrm{a}} \pm 0.35$ & $6.7^{\mathrm{a}} \pm 0.18$ & $6.65^{\mathrm{a}} \pm 0.24$ & $6.53^{\mathrm{a}} \pm 0.17$ & $6.53^{\mathrm{a}} \pm 0.05$ \\
15 & $6.78^{\mathrm{a}} \pm 0.28$ & $6.7^{\mathrm{ab}} \pm 0.00$ & $6.63^{\mathrm{ab}} \pm 0.22$ & $6.5^{\mathrm{b}} \pm 0.08$ & $6.53^{\mathrm{ab}} \pm 0.05$ \\
18 & $6.73^{\mathrm{a}} \pm 0.09$ & $6.55^{\mathrm{ab}} \pm 0.10$ & $6.5^{\mathrm{b}} \pm 0.14$ & $6.6^{\mathrm{ab}} \pm 0.11$ & $6.5^{\mathrm{b}} \pm 0.18$ \\
\hline
\end{tabular}

Remarks: The notation indicated by different superscript letters in the same column shows a significant difference (p<0.05). A: Scad fish without bay leaf extract treatment, B: Scad fish soaked in $6 \%$ of bay leaf extract, C: Scad fish soaked in 7\% of bay leaf extract, D: Scad fish soaked in $8 \%$ of bay leaf extract, E: Scad fish soaked in $9 \%$ of bay leaf extract.

\section{Organoleptic test}

The organoleptic tests on preserved scad fish included five parameters, including visual, aroma, odor, texture, and mucus parameters that create an individual experience via the senses including taste, sight, smell, and touch. The minimum acceptable score was 6 . The results of the organoleptic tests were provided at the beginning of the experiment and after 18 hours of preservation time.

\section{Visual parameter}

The results of the visual parameters at the beginning of the trial indicated the preserved scad fish in treatment A, B, $\mathrm{C}, \mathrm{D}$, and E experienced organoleptic values until the end of the storage period (18 hours). The average visual score of the beginning of the experiment in treatments A, B, C, D, and E ranged from 7.39 to 8.35. Furthermore, the average visual score at the 18 hours in treatments $\mathrm{A}, \mathrm{B}, \mathrm{C}, \mathrm{D}$, and $\mathrm{E}$ ranged from 5.48 to 6.97 (Figure 1).

\section{Aroma parameter}

The results of the aroma parameter of scad fish at the beginning of the experiment up to hour 18 of all treatments A, B, C, D, and E indicated a decrease in the organoleptic score. The average odor score at the beginning of the 
experiment in all treatments was between 7.33 and 8.31. Furthermore, the average aroma value in all treatments at hour 18 ranged from 5.8 to 6.89 (Figure 2).

\section{Odor parameter}

The results of the odor parameter of the scad fish at the beginning of the experiment in all treatments indicated a decrease of the organoleptic values after 18 hours of storage period. The average odor value in all treatments at the beginning of the experiment was between 7.28 and 8.03 (Figure 3). The odor parameter results at the 18 hours were not assessed because the total value of the bacteria exceeded the limit of microorganisms.

\section{Texture parameter}

The results of the texture parameter at the beginning of the experiment at all treatments indicated a decrease in the organoleptic values by the end of 18 hours of the storage period. The average texture value at the beginning of the experiment was between 7.18 and 8.3 for all treatments. Furthermore, the average texture value was between 6.27 and 6.92 for all treatments after 18 hours (Figure 4).

\section{Mucus parameter}

The results of the mucus parameter at the beginning of the experiment for all treatments indicated a decrease in the organoleptic values by the end of 18 hours of the storage period. The average mucus value at the beginning of the experiment for all treatments was between 7.18 and 8.3. Furthermore, the average mucus value was between 6.13 and 6.87 for all treatments after 18 hours (Figure 5).

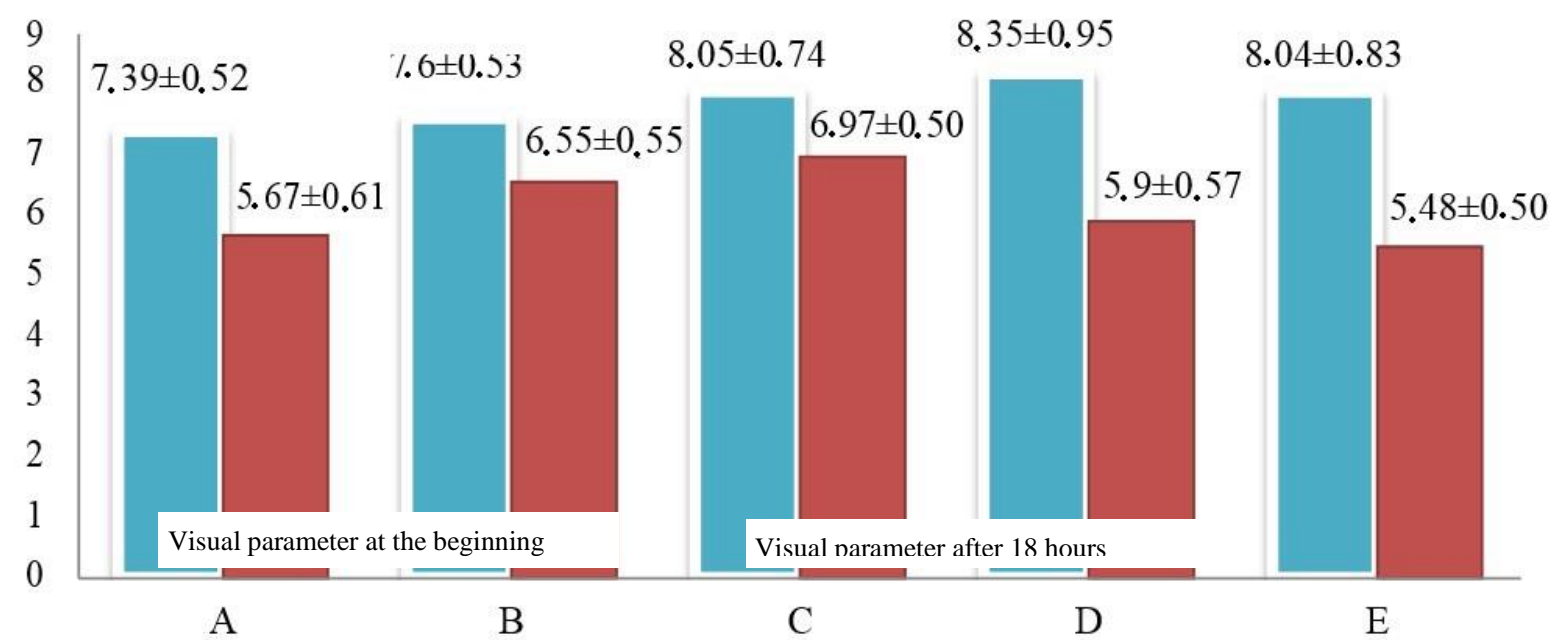

Figure 1. The results of the visual parameters of scad fish at the beginning of the experiment and after 18 hours of the storage period.

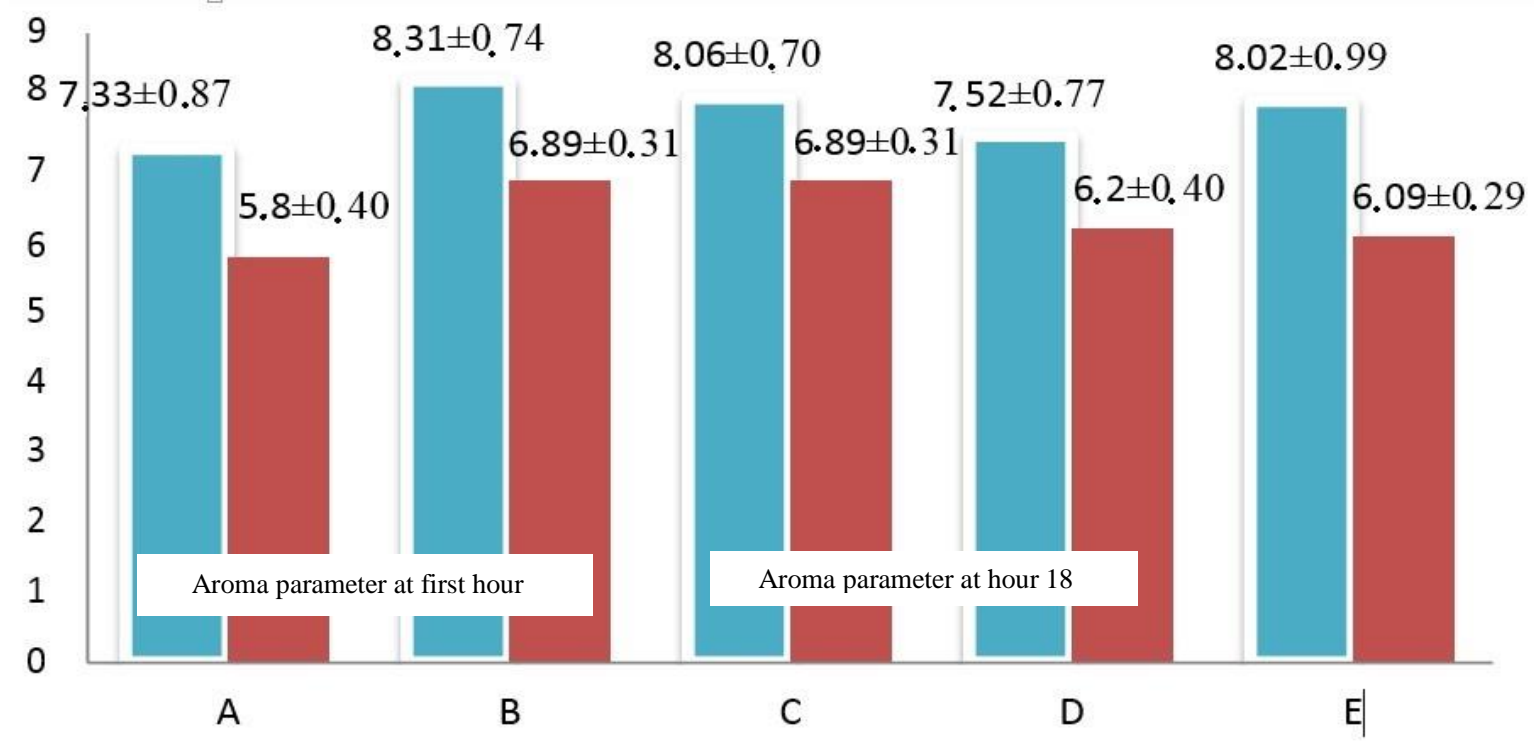

Figure 2. The results of the aroma parameters of scad fish at the beginning of the experiment and after 18 hours of storage period. 


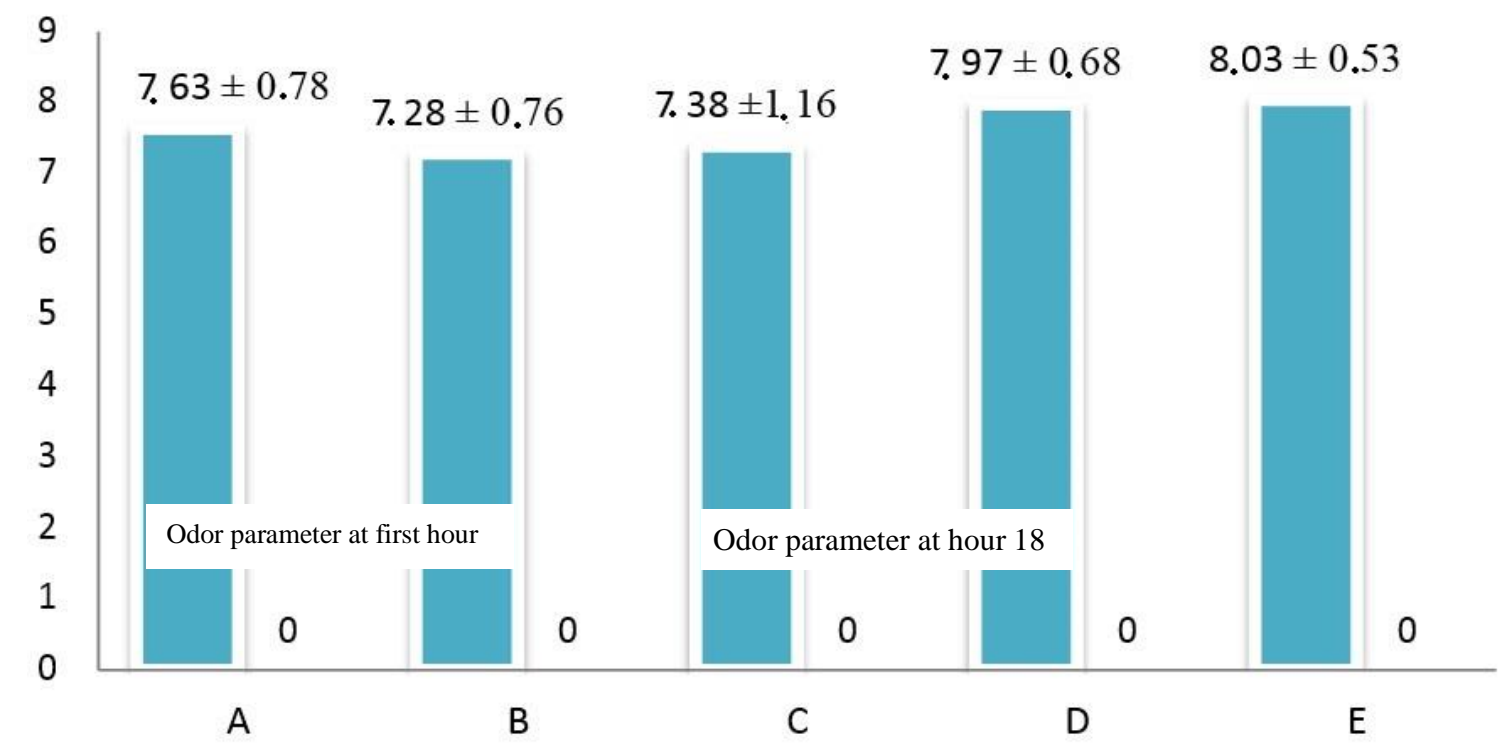

Figure 3. The results of the odor parameters of the scad fish at the beginning of the experiment and after 18 hours of the storage period.

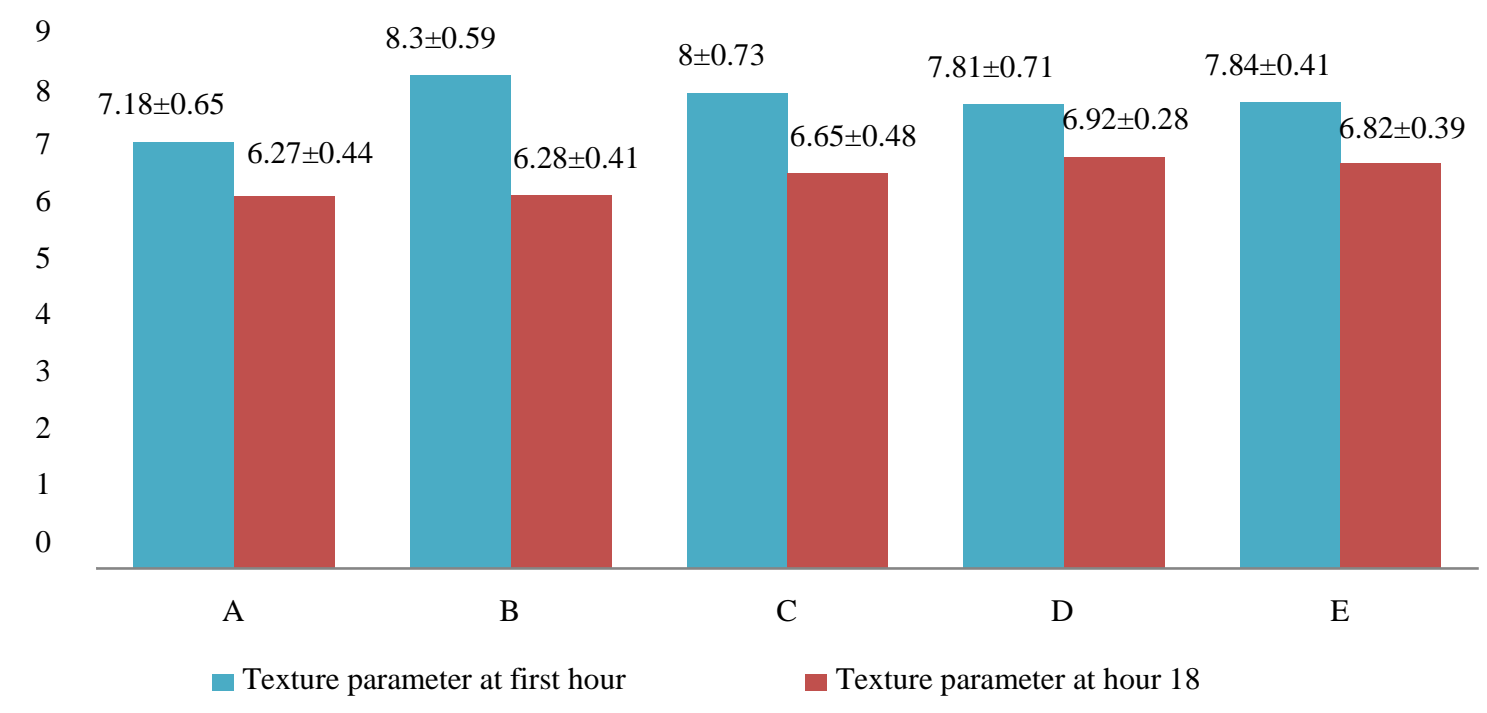

Figure 4. The results of the texture parameters of scad fish at the beginning of the experiment and after 18 hours of the storage period.

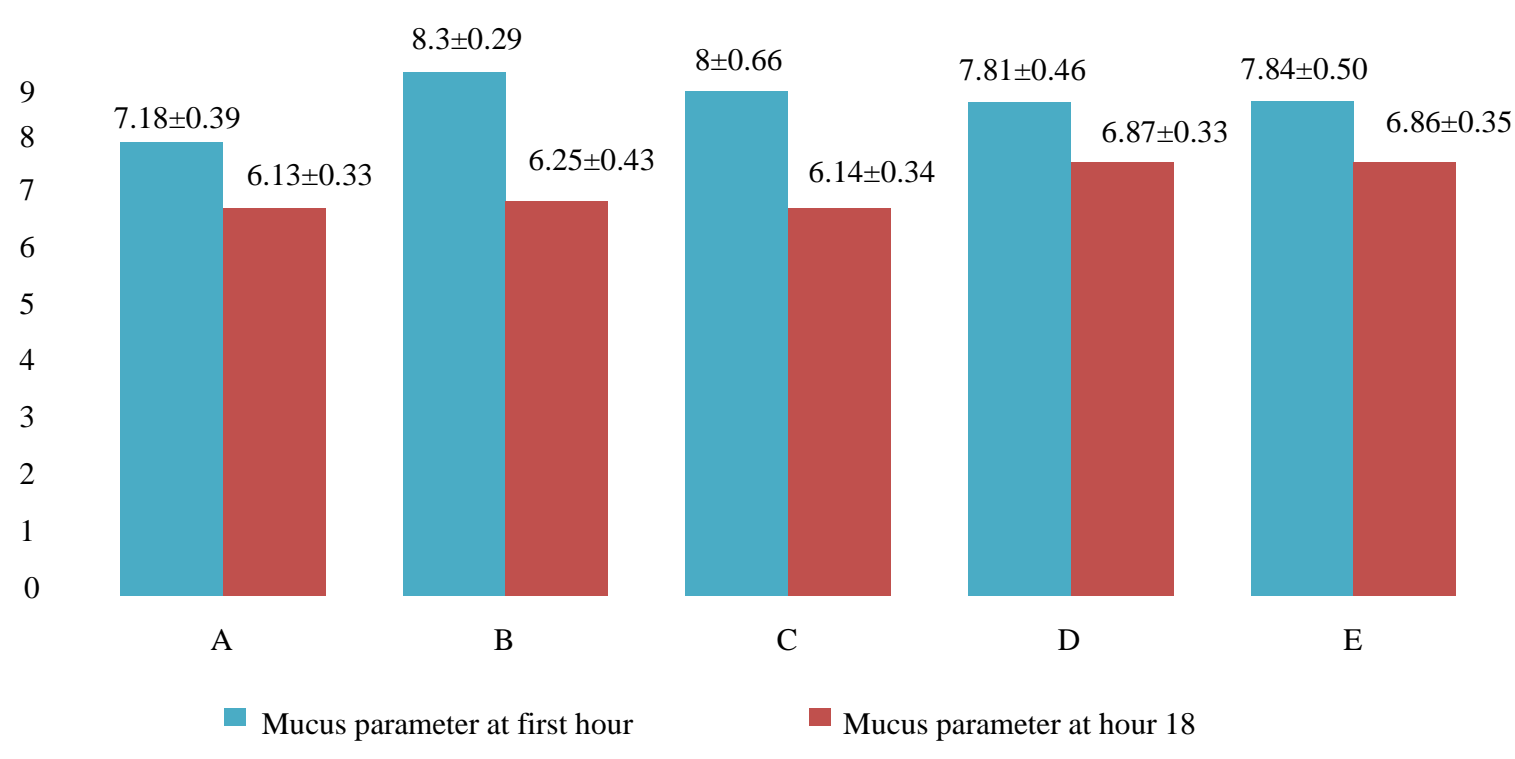

Figure 5. Mucus parameter of scad fish at the beginning of the experiment and after 18 hours of the storage period. 
Shelf life is the period in which the quality of fresh food is impaired and becomes inedible. In the present research, the shelf life was determined using the TPC of the microbiological tests, chemical tests (water level and $\mathrm{pH}$ ), and sensory tests (organoleptic test). The food product quality is influenced by the microbial content of the product as it determines consumption safety. The shelf life of food is determined by the total bacterial count in the product using a method called the TPC. The results of total bacteria calculation on the scad fish in all treatments increased constantly from the beginning of the experiment up to after 18 hours since the storage time could increase the total bacteria count. The test results of bay leaf extract on scad fish from the beginning up to 12 hours indicated that the number of microorganisms was still at the maximum growth limit of 5×105 Colony-Forming Unit (CFU)/gram (Buckle, 1987; Herawati, 2008).

Various factors that influenced microbial growth in the food products included intrinsic factors such as acidity $(\mathrm{pH})$, water activity, nutrient content, biological structure, and antimicrobial content, while the extrinsic factors included storage temperature, humidity, type and amount of gases in the environment, and preparation and processing errors. All the treatments indicated that the bay leaf extract could inhibit the bacteria for up to 12 hours. The best treatment was obtained in treatment C (7\% of bay leaf extract) because it had the lowest bacterial count among all treatments. The current result is in line with the previous study conducted by Buckle (1987) and Sahputra (2015) which suggested that a combination between $7 \%$ of bay leaf extract treatment and $8 \%$ of salt can inhibit bacteria in the milkfish (Buckle, 1987; Sahputra, 2015).

Bay leaf extract contained antibacterial compounds with high tannin, terpenoid, and flavonoid contents. These compounds could inhibit the growth of microbes. Flavonoid compounds have an important role in the inhibition of bacteria by forming complex compounds with extracellular proteins through hydrogen bonds that degrade bacterial cell membranes. Hydrogen and flavonoid bonds cause unstable cell wall structure and cell membrane and cellular deterioration. Tannin compounds play a role in shrinking cell walls and membranes to interfere with cell permeability. The impaired cell permeability means that the cell cannot perform living activities. Thus, it could inhibit bacterial growth and kill the bacteria. In addition, terpenoid compounds act as antibacterial compounds on the outer membrane of terpenoid cell walls by reacting with porin (transmembrane protein) to form strong polymer bonds. The polymer bonds caused the porin to deteriorate as a connecting gateway to reduce the permeability of the bacterial cell walls; and that caused bacterial cells to lack in the nutrient, whereby the bacterial growth is inhibited (Roslizawaty, 2013).

The water level is a factor that affects the shelf life of processed food and determines the freshness of food against microbes. The high water content causes bacteria, mold, and yeast to multiply easily. So there will be changes in the food. When stored in-room temperature, water level changes would be caused by the free water formed as a result of protein denaturation by microorganisms (Nirmala, 2016). Based on the results of the present study, the water level decreased from the beginning to the end of the storage process. This condition was caused by the evaporation of most of the water as the storage process was only stored at room temperature. The low water content led to a decrease in bacterial activity. However, based on the current research, the water level and the TPC indicated the opposite results, where the water level decreased, while the TPC increased. This phenomenon was caused by the still good water level, which allowed the bacteria to grow well. More than $30 \%$ of the water content in the food could affect bacterial growth. Elevated microbes could damage the hydrophilic protein, resulting in a reduced ability to hold water when the water level finally decreased (Siskos, 2007).

The $\mathrm{pH}$ value is an indicator that is measured to chemically determine the freshness level of fishery products. The optimal $\mathrm{pH}$ for bacterial growth is 6.5-7.5. The $\mathrm{pH}$ value of scad fish decreased from the beginning up to 18 hours. The $\mathrm{pH}$ change was caused by several factors, such as poor storage and storage temperature. The pH values obtained indicated that the scad fish marinated in bay leaf extract had an acidic $\mathrm{pH}$ value. The bay leaf boiling time affected the $\mathrm{pH}$ value of the leaf extract because the longer the leaves were boiled, the more organic acids from the leaves were extracted, resulting in a decrease in the $\mathrm{pH}$ value of the bay leaf. The $\mathrm{pH}$ value is closely related to the growth of microbes in fishery products. Fresh fish has a neutral pH, making it an ideal medium for bacterial growth (Junior, 2010). The organoleptic test on the scad fish, with and without adding bay leaf extract, included the visual, aroma, odor, texture, and mucus parameters. The result showed that at the starting hour, the quality of the fish was still acceptable by the panelists according to the Indonesia Nasional Standard with a minimum organoleptic value of 6 . At the starting hour, the appearance of the scad fish received an average value in the range of 7.39 to 8.35. Meanwhile, the results of the organoleptic test at the 18 hours of storage suggested that the visual score of the scad fish decreased from 5.48 to 6.97. The results also indicated that there was an increasing bacterial count by hour 18 . The appearance change was caused by the growth of microbe that could damage the products as the microbe were highly destructive to food.

The odor of the scad fish averaged between 7.33 to 8.31 at the beginning of the experiment. The odor value indicated that the fish was still fresh and smelled good. The fish smelled fresh since the bay leaves contained terpenoid compounds containing essential oils, which produced a distinctive but less sharp aroma. After 18 hours, the average result of the odor value decreased and was between 5.8 and 6.89. Therefore, the aroma parameter of scad fish at the 
beginning of the experiment up to hour 18 of all treatments A, B, C, D, and E indicated a decrease in the organoleptic score. Treatment A gave the lowest score, reaching 5.8 at hour 18. The lowest odor score parameter on treatment A was also supported by the result indicating the high bacterial count found in the fish, which was $8.55 \times 106$. A decrease in the organoleptic matter could occur because the room temperature could accelerate the disintegration process during the storage of the fish. These bacteria could carry out a perfect metabolism that produced a bad odor.

Initially, the scad fish began to smell an average value of between 7.28 to 8.03 , indicating that the fish was tasty, savory, or less savory. Meanwhile, after 18 hours, the odor test was not carried out by the organoleptic test due to the high TPC level of enzyme in the scad fish. In addition, the texture of the scad was given an average value in the range of 7.18 to 8.3 , indicating that the fish were solid and elastic or less elastic. This texture was caused by the salt that was added in the process of making preserved scad fish since salt could improve the texture of fish. The salt used in the process of making scad fish reduced the water contents in the fish, which made the texture more solid and firm. Meanwhile, after 18 hours, the texture of scad fish decreased from 6.27 to 6.92. Treatment A had the lowest score, 6.27 at the 18 hours. The texture parameter of treatment A was also indicated by the high bacterial count found in the fish, which was $8.55 \times 106$, compared to the other treatments. The high bacterial count was caused by microorganism activity affecting the texture changes. The protein denaturation produced a simple protein, and also decreased the protein capacity to hold water so that the texture of fish became less solid and firm.

At the starting hour, the mucus of the scad fish obtained an average score from 7.18 to 8.3 , indicating that the fish had thin and more neutral mucus and was odorless. Meanwhile, at 18 hours, the mucus content of scad fish fell from 6.13 to 6.87. The mucus parameter of the treatment is considered treatment with the lowest value of 6.13 . The mucus parameter of treatment A was also indicated by the high bacterial count found in the fish, reaching $8.55 \times 106$, compared to other treatments. Mucous could be caused by bacteria. The mucus found in the fish's skin could be used as a parameter to determine the freshness level of the scad fish by focusing on the clearness and thickness of the mucus. The mucus changes were caused by the increasing number of spoilage bacteria activity on the fish after 18 hours (Lougovois and Kyrana, 2005).

\section{CONCLUSION}

Adding bay leaf extracts to preserved scad fish indicated that the total bacterial count was lesser than the Indonesian National Standard (SNI), of $5 \times 105$ CFU/gram, which could inhibit bacterial development by 12 hours. The best result was with treatment $\mathrm{C}$ (7\% of bay leaf extract addition), as the concentration at this percentage could inhibit bacteria in preserved scad fish.

\section{DECLARATIONS}

\section{Authors' contribution}

Fuaidah designed the study, Triastuti collected the data and Pramono wrote the manuscript. Finally, all of the authors approved the final draft of the manuscript for submission.

\section{Competing interests}

The authors have not declared any conflict of interest.

\section{Acknowledgments}

Thanks to the authors and all the staff at the Faculty of Fisheries and Marine for their supports and facilities.

\section{REFERENCES}

Ariyani F, and Yennie Y (2008). Preservation of boiled salted scad mackerel (Decapterus russelli) using chitosan. Jurnal Pascapanen dan Bioteknologi Kelautan dan Perikanan 3 (2): 139-146. DOI: http://dx.doi.org/10.15578/jpbkp.v3i2.16

Buckle KA, Edwards RA, Fleet GH, Wooton M, and Purnomo H (1987). Ilmu Pangan. Terjemahan: H. Purnomo dan Adiono. Jakarta Penerbit Univ Indones. Available at: https://opac.perpusnas.go.id/DetailOpac.aspx?id=508531

Hastuti S (2010). Analisis kualitatif dan kuantitatif formaldehid pada ikan asin di Madura [Formaldehyde qualitative and quantitative analysis on salted fish in madura]. Agrointek, 4(2): 132-7. DOI: https://www.doi.org/10.21107/agrointek.v4i2.1366

Herawati H (2008). Penentuan umur simpan pada produk pangan [Determination of shelf life in food products]. Jurnal Litbang Pertanian, 27(4): 124-30. Available at: http://203.190.37.42/publikasi/p3274082.pdf

Junianingsih I (2015). Quality test of pindang cue-besek Decapterus sp. In Jangkar Village District Situbondo. Samakia: Jurnal Ilmu Perikanan, 6(2): 91-8. DOI: https://www.doi.org/10.5281/jsapi.v6i2.289

Junior MRM, Leite AV, and Dragano NRV (2010). Supercritical fluid extraction and stabilization of phenolic compounds from natural sources-review (supercritical extraction and stabilization of phenolic compounds). The Open Chemical Engineering Journal, 4: 51-60. DOI: https://www.doi.org/10.2174/1874123101004010051 
Lougovois, V. P., \& Kyrana, V. R. (2005). Freshness quality and spoilage of chill-stored fish. In Food policy, Control and Research, Nova Science Publishers, Inc. pp. 35-86. https://www.academia.edu/27627359/Freshness_Quality_and_Spoilage_of_ChillStored Fish

Nafisyah AL, Tjahjaningsih W, Kusdarwati R, Abdillah AA (2015). Pengaruh Alga Merah (Kappaphycus alvarezii) terhadap Mutu Ikan Kembung (Rastrelliger sp.) [Effect of Red Algae (Kappaphycus alvarezii) on The Quality of Mackerel (Rastrelliger sp.)]. Jurnal Ilmiah Perikanan dan Kelautan, 7(1): 87-94. DOI: http://www.dx.doi.org/10.20473/jipk.v7i1.11240

Nirmala D, Masithah ED, and Purwanto DA (2016). Kitosan Sebagai Alternatif Bahan Pengawet Kamaboko Ikan Kurisi (Nemipterus nematophorus) pada Penyimpanan Suhu Dingin [Chitosan as an Alternative Preservative Material for Curry Fish (Nemipterus nematophorus) in Cold Storage]. Jurnal Ilmiah Perikanan dan Kelautan, 8(2): 109-125. http://journal.unair.ac.id/downloadfullpapers-jipk7df6c50aa02full.pdf

Nurwijayanti, Hasdianah, and Suhita BM (2016). Rekayasa Daun Salam untuk Pengawetan Ikan dalam Upaya Menghindari Penggunaan Efek Formalin terhadap Kesehatan Tubuh [Bay Leaf Engineering for Fish Preservation in an Effort to Avoid the Use of Formalin Effects on Body Health]. STIKes Surya Mitra Husada Kediri, 1: 120-128. Available at: https://docplayer.info/46728577-Rekayasa-daun-salam-untuk-pengawetan-ikan-dalam-upaya-menghindari-penggunaan-efekformalin-terhadap-kesehatan-tubuh-stikes-surya-mitra-husada-kediri.html

Purwani E, and Muwakhidah (2008). Efek Berbagai Pengawet Alami sebagai Pengganti Formalin Terhadap Sifat Organoleptik dan Masa Simpan Daging dan Ikan [Effects of Various Natural Preservatives as Substitutes for Formalin on Organoleptic Properties and Shelf Life of Meat and Fish]. Jurnal Penelitian Sains and Teknologi, 9(1):1-14. Available at: https://publikasiilmiah.ums.ac.id/bitstream/handle/11617/414/1.\%20ENI\%20PURWANI\%202.pdf?sequence=1\&isAllowed=y

Roslizawaty, Ramadani NY, Fakhrurrazi, and Herrialfian (2013). Antibacterial Activity of Ethanol's Extract and Stew of Ant Plant (Myrmecodia sp.) Against Bakteria Escherichia coli . Jurnal Medika Veterinaria, 7(2): 91-94. http://jurnal.unsyiah.ac.id/JMV/article/download/2938/2788

Sahputra NW (2015). Daya Simpan Ikan Bandeng Yang Diawetkan Menggunakan Pengawet Alami Kombinasi Daun Salam (Eugenia polyantha, Weight.) [Shelf Life of Milkfish Preserved Using Natural Preservatives Combination of Bay Leaves (Eugenia polyantha, Weight.)] Dan Garam. Universitas Muhammadiyah Surakarta, 1: 1-11. Available at: http://eprints.ums.ac.id/35371/1/Naskah\%20Publikasi.pdf

Siskos I, Zotos A, Melidou S, and Tsikritzi R (2007). The effect of liquid smoking of fillets of trout (Salmo gairdnerii) on sensory, microbiological and chemical changes during chilled storage. Food Chemistry, 101(2): 458-464. DOI: https://www.doi.org/10.1016/j.foodchem.2006.02.002

Triarso I (2012). Potential and opportunities for developing capture fisheries business in the north coast of Central Java. Saintek Perikanan: Indonesian Journal of Fisheries Science and Technology, 8(1): 65-73. DOI: https://www.doi.org/10.14710/ijfst.8.1.65$\underline{73}$

York RK, and Sereda LM (1994). Sensory assessment of quality in fish and seafoods. In: Shahidi F., Botta J.R. (eds) Seafoods: Chemistry, Processing Technology and Quality. Springer, Boston, MA. pp 233-262. https://www.doi.org/10.1007/978-1-46152181-5_13 